\title{
Vertical distribution and sources of perylene in miocene mudstones from the northeastern Bengal Basin of Bangladesh
}

\author{
H. M. Z. Hossain \\ Department of Petroleum and Mining Engineering, Jessore University of Science and Technology, Jessore-7408, \\ Bangladesh
}

\begin{abstract}
The distributions and sources of perylene (Pery) and penta-aromatic hydrocarbons were investigated in 10 Miocene mudstones from the NE Bengal Basin, Bangladesh using gas chromatography-mass spectrometry (GC-MS). Pery concentrations were high in most of the samples, and highest levels were found in samples of strong terrigenous influence of organic matter deposited under reducing environmental conditions. Mudstones in the Bokabil Formation (upper Surma Group) contain relatively high abundances of benzofluoranthenes (Bflas), benzo $[e]$ pyrene $(\mathrm{BePy})$ and benzo $[a]$ pyrene $(\mathrm{BaPy})$ attributed to their combustion origin. Pery to pentacyclic aromatic isomers (PAIs) ratios implies an influence of diagenetic sources, whereas low $\mathrm{BaPy} / \mathrm{BePy}$ ratios indicate that these compounds were originated from combustion sources. Wood degrading fungi in arid to humid and seasonal climatic conditions was also the possible source of Pery in the studied succession.
\end{abstract}

Keywords: GC-MS; Perylene; Mudstone; Bengal Basin; Bangladesh

\section{Introduction}

Polycyclic aromatic hydrocarbons (PAHs) are widespread in both modern and ancient sediments (Aizenshtat, Z., 1973, Wakeham et al., 1979, 1980, Jiang et al., 1998, 2000, Grimalt et al., 2004, Grice et al., 2007). Generally, PAHs occur in soils (Blumer and Youngblood, 1975, Youngblood and Blumer, 1975), modern lake sediments (Giger and Schaffner, 1978, Laflamme and Hites, 1978, Wakeham et al., 1980, Gschwend and Hites, 1981), modern marine sediments (Youngblood and Blumer, 1975, Hites et al., 1977, Gschwend and Hites, 1981), river and river estuary sediments (Giger and Schaffner, 1978, Hites et al., 1980, Brown and Maher, 1992) and in river particulates (Giger and Schaffner, 1978, Brown and Maher, 1992).

Perylene (Pery) and pentacyclic aromatic isomers (PAIs; benzofluoranthenes (Bflas), benzo[e]pyrene (BePy) and benzo[a]pyrene (BaPy) consist of five condensed benzene rings, and are abundant in modern sediments (Jiang et al., 1998, Baumard et al., 1998, Readman et al., 2002, Bakhtiari et al., 2009). Pery is derived from biological precursors during post-depositional diagenesis in terrigenous sources (Aizenshtat, 1973, Laflamme and Hites, 1978, Hites et al., 1980, Tan and Heit, 1981, Tan et al., 1996, Jiang et al., 1998, Grice et al., 2009). It has been derived from both aquatic and continental organic matters under the influence of prolong reducing environments (Aizenshtat, 1973, Wakeham et al., 1979, Silliman et al., 2000, Suzuki et al., 2010). Pery may also originate from diatomaceous sediments (Wakeham et al., 1979, Venkatesan, 1988).

Bangladesh is located in the northeastern part of the Indian subcontinent (Fig. 1), which is bounded to west by the Precambrian Indian Shield Platform, to the east by the IndoBurman Ranges, to the north by the crystalline Shillong Massif, and to the south it plunges into the Bay of Bengal (Fig. 1). The study area covers Middle to Late Miocene Surma Group (Bhuban and Bokabil formations) within the Surma Basin, NE Bangladesh (Fig. 2), in terms of concentration and potential sources of Pery in mudstones. Biomarker study of the Tertiary mudstones in the eastern Bengal Basin of Bangladesh has been reported by Alam and Pearson (1993), Farhaduzzaman et al. (2012) and Hossain et al. (2009a, 2009b, 2013). The main objective of this study was to identify distribution and possible sources of Pery and PAIs in the Miocene mudstones, Surma Basin, NE Bangladesh.

\section{Geological setting}

The Bengal Basin is placed just south of the crystalline Shillong Massif, occupying entire Bangladesh, West Bengal,

\footnotetext{
*Corresponding author. e-mail: zakirgsd@yahoo.com
} 
Assam, Tripura, Myanmar and part of the Bay of Bengal (Fig. 1). This basin has been originated between the collision of three plates- Indian plate, Eurasian plate and Myanmar plate, building the extensive Himalayas and Indo-Burman Ranges, and thereby loading the lithosphere to form flanking sedimentary basins (Uddin and Lundberg, 1998). The Bengal Basin comprises three geo-tectonic provinces- the stable shelf zone, the central deep basin and the ChittagongTripura fold belt (Alam et al., 2003). The basin fills comprise $\sim 22 \mathrm{~km}$ thick sedimentary record (Alam et al., 2003), and it has been developed by the seaward prograding deltas of the Ganges and Brahmaputra river systems (Einsele et al., 1996). The Ganges and Brahmaputra rivers drain opposite flanks of the Himalaya, and drastically rising mountains carrying sediments by Brahmaputra from the northeastern Himalayas (Fig. 1). The Himalayas originated between collision of Indian and Eurasian plates and significantly uplift its northeastern part. The Ganges-Brahmaputra delta and the Bengal fan contain large volume of sediments that were input from the collision zone, characterizing physical and chemical weathering and drained by many Himalayan streams to join into the Ganges and Brahmaputra rivers.

The Surma Basin, is a rapidly subsiding sub-basin in the northeastern part of the Bengal Basin, Bangladesh and con tains hydrocarbon reserves, the only natural energy resource discovered so far in Bangladesh. Tectonically, the Surma Basin is located in the central deep basin of the Bengal Basin
(Alam et al., 2003). The stratigraphy of the Surma Basin is listed in Table I. The present paper is concentrated only the Surma Group of the Tertiary succession of Middle to Late Miocene age, NE Bengal Basin, Bangladesh. The Surma Group consists of an arenaceous lower Bhuban and argillaceous upper Bokabil formations (Alam et al., 2003). The Bhuban Formation is comprises mainly of grey sandstones, siltstones and mudstones. The overlying Bokabil Formation consists primarily of light grey mudstones, siltstones and sandstones. Sediments of the Surma Group were deposited under the strong influence of tidal currents in a deltaic to shallow marine depositional systems (Khan, 1991, Reimann, 1993, Shamsuddin and Abdullah, 1997, Alam et al., 2003).

\section{Materials and methods}

\section{Sample collection}

Ten unweathered mudstone samples were collected from hydrocarbon exploration drill core and surface outcrops in Miocene Surma Group, Sylhet succession, Bangladesh. Outcrop samples $(\mathrm{n}=3)$ were taken from section exposed along the Hari River (Hossain and Roser, 2006), and drill core samples $(n=7)$ were taken from three hydrocarbon exploration wells, namely Rashidpur-1, Fenchuganj-2 and Patharia-5 (Fig. 2 and Table II). Location of the sample sites are shown in Fig. 2. Fresh rock samples were manually crushed and subsequently washed with deionized distilled

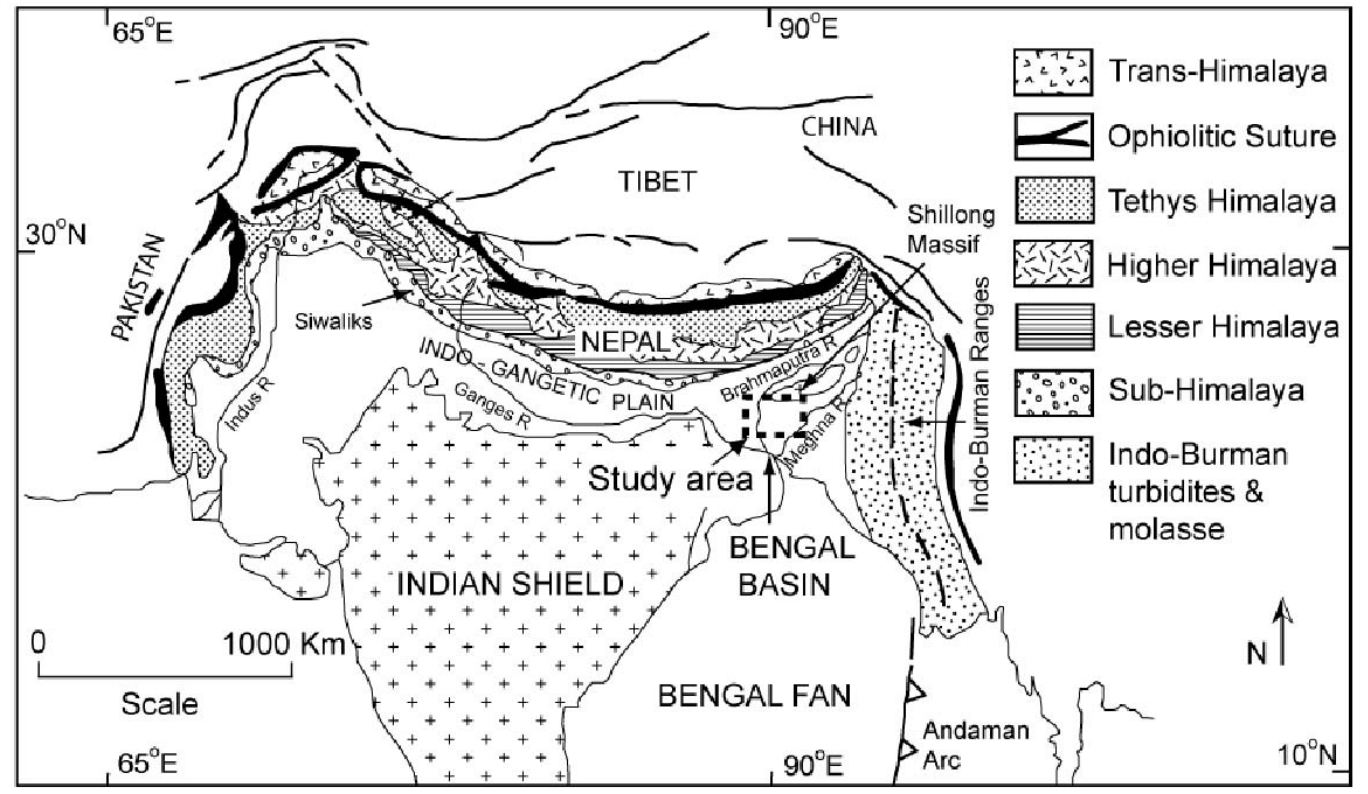

Fig. 1. Geological map of the study area showing location of the sample sites and major geographic features of the Himalaya (Hossain et al., 2010) 


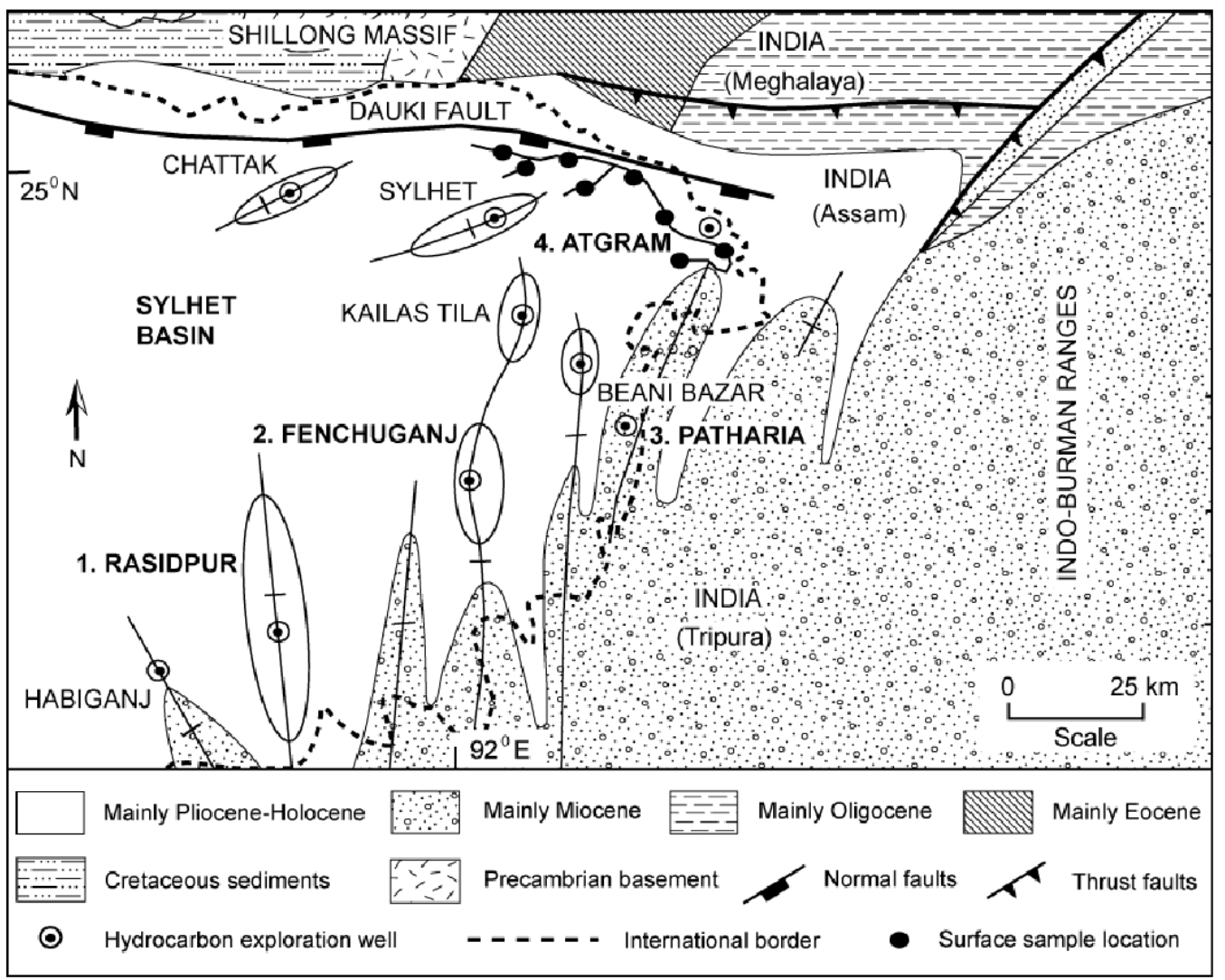

Fig. 2. Map showing location of the study area and hydrocarbon exploration wells in the NE Bengal Basin, Bangladesh (Hossain et al., 2009b). Drill core samples were taken from the Rasidpur-1, Fenchuganj-2 and Patharia-5 wells

water, and dried in an oven at $110^{\circ} \mathrm{C}$. The oven-dried samples were then powdered in a tungsten-carbide ring mill for 25 to $45 \mathrm{~s}$.

\section{Column chromatography}

Approximately $40 \mathrm{~g}$ of each powdered sample were extracted in a Soxhlet apparatus for 72 hours using a mixture (9:1) of dichloromethane (DCM) and methanol (MeOH). Elemental sulfur was removed by using $\mathrm{Cu}$ granules. The solvent was separated using a rotary evaporator. Saturated hydrocarbons and aromatic hydrocarbons were then separated using thin layer chromatography on fully activated silica gel (Kiselgel 60 PF254, Merck) eluting with $n$-hexane.

\section{Gas chromatography-mass spectrometry (GC-MS)}

The aromatic hydrocarbon fractions of all samples were analyzed by GC-MS with a Shimadzu QP2010 instrument at Shimane University, Japan. The chromatograph was equipped with an automatic temperature programmable injection system. A fused silica capillary column, DB-5MS of $30 \mathrm{~m}$ and $0.25 \mathrm{~mm}$ i.d. was used. The column temperature was programmed from 50 to $300^{\circ} \mathrm{C}$ at $8^{\circ} \mathrm{C} / \mathrm{min}$. Helium was used the carrier gas. GC-MS analyses were performed initially on a Finnigan MAT TSQ-700 system using electron impact ionization $(70 \mathrm{eV})$. Full scan spectra were recorded over a range $m / z 50$ to 850 at a scan rate of $0.5 \mathrm{~s}$. Identification of Pery $(\mathrm{m} / \mathrm{z}=252)$ and PAIs $(\mathrm{m} / \mathrm{z}=252)$ in the biomarkers were monitored by comparing the retention time and mass spectra with published data.

\section{Results and discussion}

Distribution of Pery and PAIs were examined from the Miocene Surma Group (Bhuban and Bokabil formations) mudstones, NE Bengal Basin, Bangladesh (Fig. 3). The experimental data (\%) is shown in Table II (Hossain et al., 2013). Vertical distribution of Pery and PAIs are illustrated in Fig. 4. Benzo[b]fluoranthene, benzo[j]fluoranthene and benzo[ $k]$ fluoranthene could not fully separate with the GC- 
Table I. Stratigraphy of the NE Bengal Basin, Bangladesh (Khan, 1991; Reimann, 1993)

\begin{tabular}{|c|c|c|c|}
\hline Age & Group & Formation & Lithology \\
\hline Recent & Alluvium & Alluvium & Sand, silt and clay \\
\hline Late Pleistocene & Dihing & Dihing & Sandstone with interbedded mudstone \\
\hline Pliocene-Pleistocene & Dupitila & Dupitila & Pebbly sandstone and sandstone with subordinate siltstone \\
\hline Late Miocene-Pliocene & Tipam & $\begin{array}{l}\text { Girujan Clay } \\
\text { Tipam Sandstone }\end{array}$ & $\begin{array}{l}\text { Mottled clay with subordinate sandy clay and sandstone } \\
\text { Massive sandstone with subordinate mudstone }\end{array}$ \\
\hline Middle-late Miocene & Surma & $\begin{array}{l}\text { Bokabil } \\
\text { Bhuban }\end{array}$ & $\begin{array}{l}\text { Mudstone with interbedded, sandstone and siltstone } \\
\text { Alternation of sandstone, siltstone and mudstone }\end{array}$ \\
\hline Late Eocene-early & Barail & Renji & Sandstone, mudstone and coal lenses \\
\hline Miocene & & Jenam & Mudstone, siltstone and sandstone \\
\hline Late Eocene & & Kopili Shale & Shale with subordinate sandstone and thin limestone \\
\hline Early-middle Eocene & Jaintia & Sylhet Limestone & Fossiliferous limestone \\
\hline Paleocene-early Eocene & & Tura Sandstone & $\begin{array}{l}\text { Alternation of sandstone and limestone, with mudstone and } \\
\text { coal seams }\end{array}$ \\
\hline
\end{tabular}

MS methods. Bflas are integrated as sum from benzo[b]fluoranthene, benzo[j]fluoranthene and benzo[ $k]$ fluoranthene. Among the PAIs, distributions of BePy are relatively higher than Bflas and BaPy (Table II). Abundances of Bflas are high in the upper Bokabil samples, whereas contents decrease with increasing depth of the lower Bokabil Formation (Fig. 4). Bflas in the Bhuban Formation mudstones range from 9 to $22 \%$, whereas in the Bokabil Formation concentrations of Bflas are relatively high range from 9 to $35 \%$ (Table II). Vertical distributions of PAHs show almost similar pattern except BaPy (Fig. 4). Relatively high concentrations of Bflas and BePy are present in the upper part of the Bokabil mudstones, subsequently high TOC contents inferring that distribution may controlled by organic carbon. In the Bokabil Formation, abundances of Pery increases with different depth intervals (e.g., Z-31 and Z-35) and the samples are dominated by higher plant organic matter (Hossain et al., 2009a). The relative abundances of Pery in the underlying Bhuban Formation are ranging from 41 to $73 \%$ (Table II; Fig. 4). These highest values of Pery in the studied mudstones together elevated terrestrial organic matter in varying depths moreover imply in situ biogenic sources (Agbozu and Opuene, 2009). Grimalt et al. (2004) and Grice et al. (2009) suggested that Pery concentration increases during depth of burial of organic matter. Vertical distribution of Pery in the Tertiary succession shows variable contents (Fig. 4). $T_{\max }$ values in the Surma Group samples range from 435 to 449 ${ }^{\circ} \mathrm{C}$ (Table II; Hossain et al., 2009a), and vitrinite reflectance (Ro) values range from 0.45 to $0.60 \%$ (Shamsuddin and Khan, 1991), inferring that the occurrence of Pery in the

Table II. Abundances (\%) of perylene (Pery), benzofluoranthenes (Bflas), benzo[e] pyrene (BePy) and benzo[a] pyrene (BaPy) in Miocene mudstones, NE Bengal Basin, Bangladesh (Hossain et al, 2013). Abbreviation: pIAs, Pentacylic aromatic isomers (Bflas + BePay + BaPy); TOC, Total organic carbon. TOC* and $T_{\max }{ }^{\circ} \mathrm{C}$ data from Hossain et al $\left(2009_{\mathrm{a}}\right)$

\begin{tabular}{lllllllllll}
\hline \multicolumn{1}{c}{ Age } & Well/local name & Group & Formation & Pery & Bflas & BePy & BaPy & PAIs & TOC $^{*}$ & $T_{\max }{ }^{\circ} \mathrm{C}^{*}$ \\
\hline Z-31 & BDR camp & Surma & Bokabil & 74.89 & 10.59 & 12.09 & 2.43 & 25.11 & 0.31 & 438 \\
ZH-122 & Rashidpur-1 & Surma & Bokabil & 18.90 & 34.28 & 40.64 & 6.18 & 81.10 & 0.53 & 449 \\
ZH-126 & Rasidpur-1 & Surma & Bokabil & 23.22 & 35.01 & 39.56 & 2.21 & 76.78 & 0.48 & 448 \\
Z-35 & Baragang & Surma & Bokabil & 74.52 & 9.05 & 14.53 & 1.90 & 25.48 & 0.39 & 439 \\
ZH-128 & Rasidpur-1 & Surma & Bokabil & 42.56 & 17.44 & 38.20 & 1.80 & 57.44 & 0.40 & 447 \\
ZH-55 & Fenchuganj-2 & Surma & Bokabil & 48.52 & 19.30 & 28.66 & 3.52 & 51.48 & 0.32 & 442 \\
ZH-59 & Fenchuganj-2 & Surma & Bhuban & 41.41 & 21.87 & 35.30 & 1.41 & 58.59 & 0.38 & 442 \\
ZH-88 & Fenchuganj-2 & Surma & Bhuban & 72.57 & 9.05 & 14.88 & 3.50 & 27.43 & 0.39 & 445 \\
ZH-14 & Patharia-5 & Surma & Bhuban & 53.78 & 13.87 & 27.32 & 5.03 & 46.22 & 0.46 & 436 \\
Z-43 & Tetultala & Surma & Bhuban & 65.54 & 14.44 & 18.26 & 1.75 & 34.46 & 0.38 & 438 \\
\hline
\end{tabular}




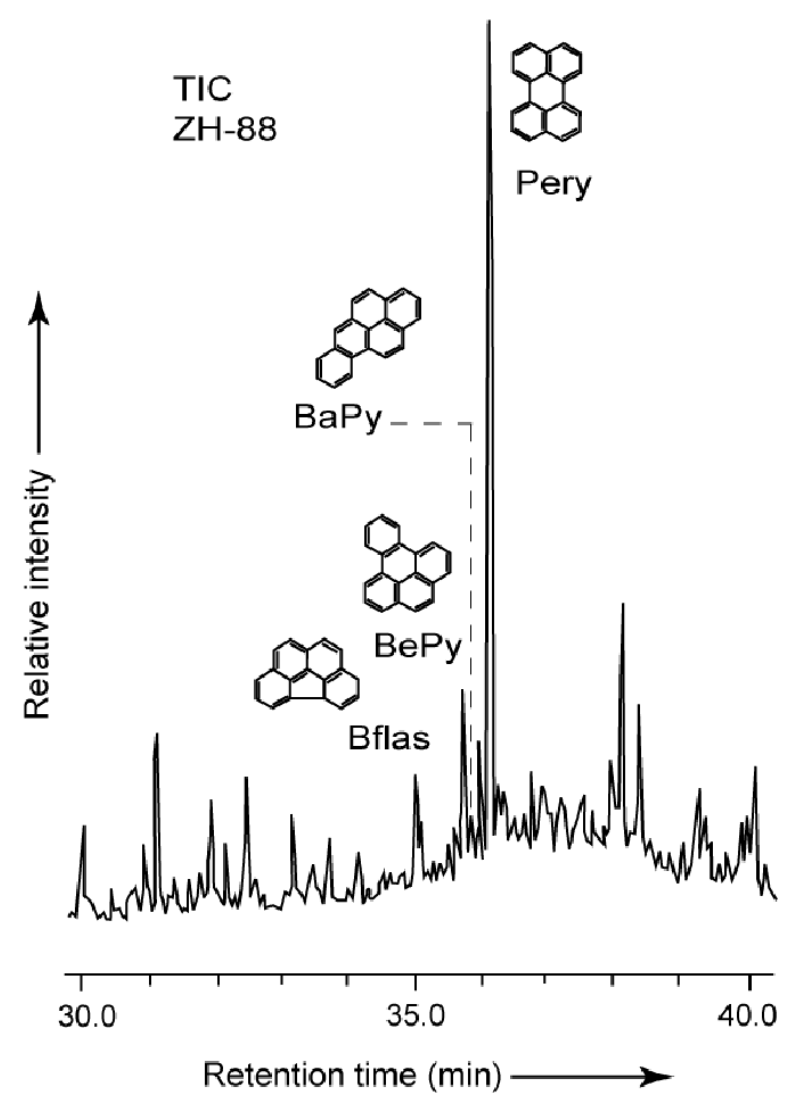

Fig. 3. Total ion chromatogram (TIC) for aromatic fractions of representative Miocene mudstone (sample no. ZH-88), NE Bengal Basin, Bangladesh. Abbreviations as in Table II

mudstones is seem to be organic source dependent and does not show the dependence on maturity. This result is in good agreement with previous study of tri-aromatic hydrocarbons in the Surma Group mudstones (Hossain et al., 2009b), NE Bengal Basin, Bangladesh suggesting that phenanthrene, methylphenanthrenes and dimethylphenanthrene isomers were likely to be primarily controlled by source input rather than by thermal maturity.

Pery is abundant in marine, lake and river sediments either aquatic or terrigenous in anoxic environments (Hites et al., 1980, Silliman et al., 1998, Jiang et al., 2000, Grimalt et al., 2004). Grice et al. (2009) and Nabbefeld et al. (2010) reported that Pery probably attributed to a source from wooddegrading fungi. Pery may also originate from combustion sources (Baumard et al., 1998, Readman et al., 2002, Bakhtiari et al., 2009, Fan et al., 2011). Hossain et al. (2009a) suggested that organic matter in the Surma Group was deposited in a sea-water influenced anoxic environmental condition, as indicated by lower pristane/phytane ratios $(\sim 1)$. Sediments in the Surma Group were accumulated in deltaic to shallow marine environments (Reimann, 1993, Alam et al., 2003). Organic matter in the Surma Group was originated from mainly phytoplankton and minor influence from terrestrial higher plants (Hossain et al., 2009a). Pery is formed by diagenetic transformation of marine precursors (Readman et al., 2002). The Surma Group sediments were deposited during repeated marine transgression and regression phases, and last marine incursion occurred at the top of the Bokabil Formation (Alam et al., 2003, Hossain et al., $2010)$. The high relative abundance of Pery ( $75 \%)$ is present in upper most part of the samples, ascribed to be deposited in reducing environment. Pery has been derived from perylenequinone structures of fungus comb as well as in modern plants, and it is generally developed in anoxic condition (Aizenshtat, 1973, Grice et al., 2009, Suzuki et al., 2010). The fungus combs are widely distributed on woody materials in the tropical environments, e.g., South Asia, North America and Brazil (Bakhtiari et al., 2009). Therefore, Pery in the studied Surma Group may be input from the activity of fungus comb on woody plants. Recently, Hossain et al. (2013) reported that Pery in the Tertiary Sylhet succession, NE Bengal Basin was derived from fungi with different climatic conditions mostly arid to humid and seasonal.

The concentrations of Pery relative to PAIs are significant for combustion as well as diagenetic sources (Hites et al., 1980, Venkatesan, 1988, Baumard et al., 1998, Readman et al., 2002, Agbozu and Opuene, 2009, Bakhtiari et al., 2009, Fan et al., 2011). Pery concentrations $>10 \%$ relative to the PAIs suggesting diagenetic origin of terrestrial organic matter (Hites et al., 1980, Venkatesan, 1988) and <10\% representing pyrolytic/combustion origin (Baumard et al., 1998, Readman et al., 2002, Bakhtiari et al., 2009). Tolosa et al. (2004) reported that Pery over PAIs ratios $<20 \%$ probably originated from pyrolytic sources. The value of Pery to PAIs in the Surma Group mudstones are all $>20 \%$ (range from $\sim 25$ to $77 \%$ ) therefore suggested that a greater influence of diagenetic sources. Among the combustion derived PAHs, Bflas and BePy may be the best example of the original combustion products (Jiang et al., 1998). Smith et al. (1995) suggested that combustion derived PAHs have been modified through sedimentary alkylation procedures. Bflas and BePy are relatively less susceptible to alkylation processes and/or post-depositional modifications (Jiang et al., 1998). BePy may also originate from forest fires and peat fires (Jiang et 


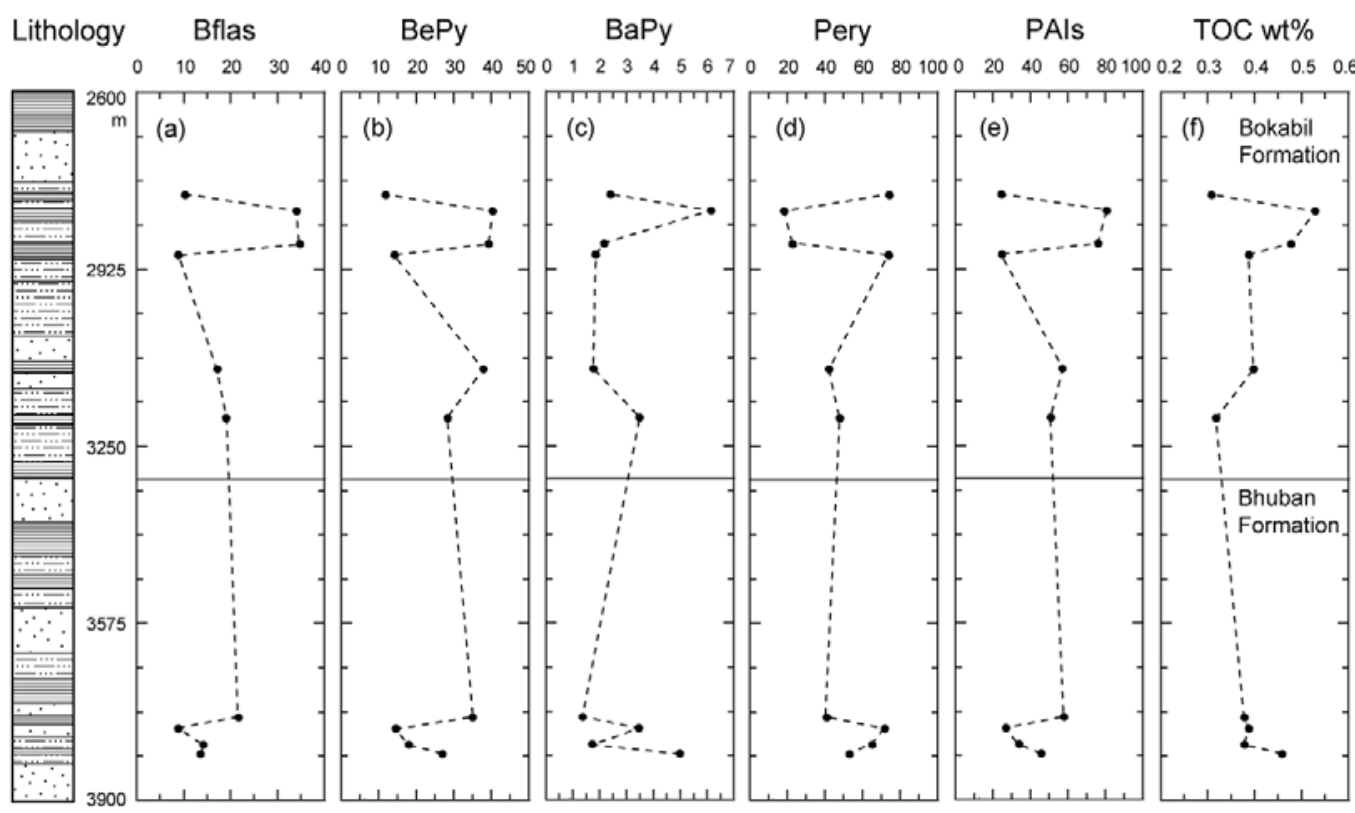

Legend : $\because$ Sandstone 5 Siltstone

Fig. 4. Vertical distributions of Bflas, BePy, BaPy, Pery, PAIs and TOC in Miocene mudstones, NE Bengal Basin, Bangladesh

al., 1998). The high relative abundances of BePy and Bflas to BaPy in the samples studied suggesting that a significant contribution of these PAHs from combustion of paleovegetation either forest fires or peat fires. The isomer concentration ratio of $\mathrm{BaPy} / \mathrm{BePy}$ has been used to identify origin of PAHs (Khalili et al., 1995). The ratios of BaPy/BePy in the Surma Group mudstones range from 0.04 to 0.24 indicating combustion sources (Khalili et al., 1995).

High contents of Pery in mudstones are likely to be derived from erosion of soils or ancient sediments during steadystate environmental condition (Fan et al., 2011). High abundances of Pery in sediments are sometimes attributed to preferential retaining of PAHs by high total organic carbon (TOC) in the sediments (Opuene et al., 2007, Bakhtiari et al., 2009, Fan et al., 2011). TOC data sources are from Hossain et al. (2009a). Concentration of TOC varies between 0.31 to $0.53 \%$, with relatively high values in middle of both formations. Low Pery values in mudstones therefore contain high TOC (Fig. 4). Correlation between Pery and TOC contents are poor (figure not illustrated), and even shows negative trend, inferring that organic carbon may not be fully responsible for the influx of Pery in the Surma Group mudstones. Distribution of PAIs and TOC is mostly identical (Fig. 4), suggesting a comparable source trends.

\section{Conclusion}

The occurrences of Pery and penta-aromatic hydrocarbons were investigated in 10 Miocene mudstones from the $\mathrm{NE}$ Bengal Basin, Bangladesh. The highest concentrations of Pery were identified in outcrop samples, and highest levels were found in samples of strong terrigenous influence of organic matter deposited under anoxic environmental conditions. Bflas, BePy and BaPy in the upper Surma Group are relatively high, suggesting that the PAHs were derived from combustion sources. Pery to PAIs ratios implies an influence of diagenetic sources and/or in situ biogenic origin, whereas low $\mathrm{BaPy} / \mathrm{BePy}$ ratios indicate that these compounds were originated from combustion sources. Wood degrading fungi in arid to humid and seasonal climatic conditions was also the possible source of Pery in the studied succession.

\section{Acknowledgement}

The author would like to thank Bangladesh Petroleum Exploration and Production Company (BAPEX) and Bangladesh Oil, Gas and Mineral Corporation (PETROBANGLA) for providing core and well log data. Special thanks are due to Profs. M.S.-U.-Islam, M.K. Roy, I. Hossain and A.K.M.M. Kabir, for their kind help during 
fieldwork and to Prof. Y. Sampei for guidance and access to the GC-MS facilities, and an anonymous reviewer for constructive and helpful comments in this paper.

\section{References}

Aizenshtat Z (1973), Perylene and its geochemical significance. Geochim. Cosmochim. Acta 37: 559-567.

Agbozu IE and Opuene K (2009), Occurrence and diagenetic evolution of perylene in the sediments of Oginigba Creek, Southern Nigeria. Int. J. Environ. Res. 3: 117120.

Alam M and Pearson MJ (1993), Bicadinanes and other terrestrial terpenoids in immature Oligocene sedimentary rocks and a related oil from the Surma Basin, NE Bangladesh. Org. Geochem. 20: 539-554.

Alam M, Alam MM, Curray JR, Chowdhury MLR and Gani MR (2003), An overview of the sedimentary geology of the Bengal Basin in relation to the regional tectonic framework and basin-fill history. Sedim. Geol.155: 179-208.

Bakhtiari AR, Zakaria MP, Yaziz MI, Lajis MNH, Bi X and Rahim MCA (2009), Vertical distribution and source identification of polycyclic aromatic hydrocarbons in anoxic sediment cores of Chini Lake, Malaysia: Perylene as indicator of land plant-derived hydrocarbons. Appl. Geochem. 24: 1777-1787.

Baumard P, Budzinski H and Garrigues P (1998), Polycyclic aromatic hydrocarbons in sediments and mussels of the western Mediterranean Sea. Environ. Toxicol. Chem. 17: 765-776.

Blumer M and Youngblood WW (1975), Polycyclic aromatic hydrocarbons in soils and recent sediments. Science 188: 53-55.

Brown G and Maher W (1992), The occurrence, distribution and sources of polycyclic aromatic hydrocarbons in the sediments of the George River Estuary, Australia. Org. Geochem. 18: 657-668.

Einsele G, Ratschbacher L and Wetzel A (1996), The Himalaya-Bengal Fan denudation-accumulation system during the past $20 \mathrm{Ma}$. J. Geol. 104: 163-184.

Fan C-W, Shiue J, Wu C-Y and Wu C-Y (2011), Perylene dominance in sediments from a subtropical high mountain lake. Org. Geochem. 42: 116-119.

Farhaduzzaman M, Abdullah WH, Islam MA and Pearson MJ (2012), Source rock potential of organic-rich shales in the Tertiary Bhuban and Bokabil formations, Bengal
Basin, Bangladesh. J. Petrol. Geol. 35: 357-376.

Giger W and Schaffner C (1978), Determination of polycyclic aromatic hydrocarbons in the environment by glass capillary gas chromatography. Anal. Chem. 50: 243-249.

Grice K, Lu H, Atahan P, Asif M, Hallmann C, Greenwood P, Maslen E, Tulipani S, Williford K and Dodson J (2009), New insights into the origin of perylene in geological samples. Geochim. Cosmochim. Acta 73: 65316543.

Grimalt JO, Drooge BLV, Ribes A, Fernández P and Appleby $P$ (2004), Polycyclic aromatic hydrocarbon composition in soils and sediments of high altitude lakes. Environ. Pollut. 131: 13-24.

Gschwend PM and Hites RA (1981), Fluxes of polycyclic aromatic hydrocarbons to marine and lacustrine sediments in the northeastern United States. Geochim. Cosmochim. Acta 45: 2359-2367.

Hiller K and Elahi M (1984), Structural development and hydrocarbon entrapment in the Surma Basin, Bangladesh (northwest Indo-Burman fold belt). Fifth Offshore South East Asia Conference, Singapore, p. 650-663.

Hites RA, Laflamme RE and Farrington JW (1977), Sedimentary polycyclic aromatic hydrocarbons: the historical records. Science 198: 829-831.

Hites RA, Laflamme RE, Windsor Jr JG, Farrington JW and Werner GD (1980), Polycyclic aromatic hydrocarbons in an anoxic sediment core from the Pettaquamscutt River (Rhode Island, USA). Geochim. Cosmochim. Acta 44: 873-878.

Hossain HMZ, Roser BP and Kimura J-I (2010), Petrography and whole-rock geochemistry of the Tertiary Sylhet succession, northeastern Bengal Basin, Bangladesh: Provenance and source area weathering. Sedim. Geol. 228: 171-183.

Hossain HMZ, Sampei Y and Roser BP (2009a) Characterization of organic matter and depositional environment of Tertiary mudstones from the Sylhet Basin, Bangladesh. Org. Geochem. 40: 743-754.

Hossain HMZ, Sampei Y and Roser BP (2009b), Influence of organic matter type on the distribution of tri-aromatic hydrocarbons in Tertiary mudstones in the Sylhet Basin, Bangladesh. Res. Org. Geochem. 25: 39-52.

Hossain HMZ, Sampei Y and Roser BP (2013), Polycyclic aromatic hydrocarbons (PAHs) in late Eocene to early 
Pleistocene mudstones of the Sylhet succession, NE Bengal Basin, Bangladesh: Implications for source and paleoclimate conditions during Himalayan uplift. Org. Geochem. 56: 25-39.

Jiang C, Alexander R, Kagi RI and Murray AP (1998), Polycyclic aromatic hydrocarbons in ancient sediments and their relationships to palaeoclimate. Org. Geochem 29: 1721-1735.

Jiang C, Alexander R, Kagi RI and Murray AP (2000), Origin of perylene in ancient sediments and its geological significance. Org. Geochem 31: 1545-1559.

Khalili NR, Scheff PA and Holsen TM (1995), PAH source fingerprints for coke ovens, diesel and gasoline engines, highway tunnels, and wood combustion emissions. Atmos. Environ. 29: 533-542.

Khan FH (1991), Geology of Bangladesh. The University Press Limited, Dhaka, pp. 207.

Laflamme RE and Hites RA (1978), The global distribution of polycyclic aromatic hydrocarbons in recent sediments. Geochim. Cosmochim. Acta 42: 289-303.

Nabbefeld B, Grice K, Summons RE, Hays LE and Cao C (2010), Significance of polycyclic aromatic hydrocarbons (PAHs) in Permian/Triassic boundary sections. Appl. Geochem. 25: 1374-1382.

Opuene K, Agbozu IE and Ekeh LE (2007), Identification of perylene in sediments: occurrence and diagenetic evolution. Int. J. Environ. Sci. Tech. 4: 457-462.

Readman JW, Fillmann G, Tolosa I, Bartocci J, Villeneuve P, Catinni C and Mee LD (2002), Petroleum and PAH contamination of Black Sea. Mar. Pollut. Bull. 44: 4862 .

Reimann K-U (1993), Geology of Bangladesh. Gebrüder Borntraeger, Berlin, pp. 160.

Shamsuddin AHM and Abdullah SKM (1997), Geologic evolution of the Bengal Basin and its implication in hydrocarbon exploration in Bangladesh. Indian $J$. Geol. 69: 93-121.

Shamsuddin AHM and Khan SI (1991), Geochemical criteria of migration of natural gases in the Miocene sediments of the Bengal Foredeep, Bangladesh. $J$. Southeast Asian Earth Sci. 5: 89-100.

Silliman JE, Meyers PA and Eadie BJ (1998), Perylene: an indicator of alteration processes or precursor materials? Org. Geochem. 29: 1737-1744.
Silliman JE, Meyers PA, Ostrom PH, Ostrom NE and Eadie BJ (2000), Insights into the origin of perylene from isotopic analyses of sediments from Saanich Inlet, British Columbia. Org. Geochem. 31: 1133-1142.

Suzuki N, Yessalina S and Kikuchi T (2010), Probable fungal origin of perylene in Late Cretaceous to Paleogene terrestrial sedimentary rocks of northeastern Japan as indicated from stable carbon isotopes. Org. Geochem. 41: $234-241$.

Tan YL and Heit M (1981), Biogenic and abiogenic polynuclear aromatic hydrocarbons in sediments from two remote Adirondack lakes. Geochim. Cosmochim. Acta 45: 2267-2279.

Tan YL, Kong A and Monetti M (1996), Biogenic polycyclic aromatic hydrocarbons in an Alaskan arctic lake sediment. Polycycl. Aromat. Comp. 9: 185-192.

Tolosa I, de Mora S, Sheikholeslami MR, Villeneuve JP, Bartocci J and Cattini C (2004), Aliphatic and aromatic hydrocarbons in coastal Caspian Sea sediments. Mar. Pollut. Bull. 48: 44-60.

Uddin A and Lundberg N (1998), Cenozoic history of the Himalayan-Bengal system: sand composition in the Bengal basin, Bangladesh. GSSA Bull. Geol. Soc. Am. Bull. 110: 497-511.

Venkatesan MI (1988), Occurrence and possible sources of perylene in marine sediments - a review. Mar. Chem. 25: $1-27$.

Wakeham S, Schaffner C and Giger G (1980), Polycyclic aromatic hydrocarbons in recent lake sediments: II. Compounds derived from biogenic precursors during early diagenesis. Geochim. Cosmochim. Acta 44: 415429.

Wakeham SG, Schaffner C, Giger W, Boon JJ and Leeuw JWD (1979), Perylene in sediments from the Namibian Shelf. Geochim. Cosmochim. Acta 43: 1141-1144.

Youngblood WW and Blumer M (1975), Polycyclic aromatic hydrocarbons in the environment: homologous series in soils and recent sediments. Geochim. Cosmochim. Acta 39: 1303-1314.

Received: 24 June 2013; Revised:03 October 2013; Accepted: 23 December 2013. 